\title{
Rostock zooplankton studies off West Africa
}

\author{
L. Postel $^{1}$, E. A. Arndt ${ }^{2} \&$ U. Brenning ${ }^{2}$ \\ ${ }^{1}$ Baltic Sea Research Institute at the University of Rostock; \\ 18119 Warnemünde, Germany \\ ${ }^{2}$ University of Rostock, Department of Biology; 18055 Rostock, Germany
}

\begin{abstract}
Since the beginning of the 'seventies, upwelling research has become increasingly popular in the path of the Canary and Benguela Current, because of economic consideration, particularly in relation to fisheries and marine geology. Many expeditions were carried out between 1970 and 1977, including 8 cruises of the German R. V. "A. v. Humboldt" operating from Rostock. Measurements covered scales ranging in time from minutes to several years and in space from hundreds of metres to several thousands of kilometres. Zooplankton studies focussed on quantitative, metabolic, taxonomic, and parasitological aspects. Plankton was collected with a WP-2UNESCO standard net to a maximum depth of $200 \mathrm{~m}$. The epipelagic mesozooplankton consists mainly of copepods, especially calanoids with developmental times of about 20 to 23 days. After an upwelling event, zooplankton is able to double its biomass. This typical biomass increase is independent of coastal distance and depth. The upwelling response lasts about 3 weeks in nearsurface waters, and 6 to 8 weeks in depths below $75 \mathrm{~m}$. A relationship was observed between the duration of seasonal upwelling (that means the numbers of single upwelling events) and the cumulative increase of biomass. This net growth rate of zooplankton biomass is most pronounced at the shelf break, the area with the highest fish biomass, and in the upper $25 \mathrm{~m}$. Differences between the expected and the real rate values in conjunction with the known amount of nutritive demands of fishes allow the estimation of the fish biomass in a given area. The near coastal Ekman upwelling, which is an event in the time scale of about two weeks, also shows seasonality in some areas. Off Northwest Africa the largest expansion was recorded in the first half of the year, extending from $10^{\circ}$ $\mathrm{N}$ to $24^{\circ} \mathrm{N}$, more than $400 \mathrm{~km}$ offshore and at least down to $200 \mathrm{~m}$. It contracts in the second half of the year to an area between $20^{\circ} \mathrm{N}$ and $22^{\circ} \mathrm{N}, 100$ to $200 \mathrm{~km}$ off the coast and in an average depth of $25 \mathrm{~m}$. These zooplankton biomass patterns are superimposed by mesoscale phenomena, originated by other than Ekman upwelling events. Those are, for example, long coastal parallel waves, producing cells of intensified upwelling and downwelling, and eddies, caused by instabilities in a frontal zone parallel to the coast. Different water masses can be distinguished by indicator species, species combinations or the significant absence of species. This was demonstrated for chaetognaths. The calanoid Calanus helgolandicus (Claus, 1863), a typical species of the North Atlantic, indicates North Atlantic Central Water, whereas Calanoides carinatus (Krøyer,1849) is an indicator of South Atlantic Central Water. Finally, comparisons of near coastal current regimes, transport velocities, and developmental rates of calanoids allow one to conclude that a suitable mechanism is present to maintain plankton in the coastal environment.
\end{abstract}

\section{INTRODUCTION}

Economic reasons, relating particularly to fisheries and marine geology, encouraged upwelling research in the Canary and Benguela Current from the beginning of the 'seventies. At least during the CINECA programme (Cooperative Investigation of the Northern Part of the Eastern Central Atlantic), which was carried out under the umbrella 
of ICES, 14 countries participated in about 100 expeditions between 1970 and 1977 (Smed, 1982). This included 8 cruises of the German R. V. "A. v. Humboldt" operating from Rostock. These studies of the Warnemünde Institute of Marine Research and Rostock University have been sporadically continued up to now and extended into Namibian waters and the central part of the Atlantic. Measurements covered time scales ranging from minutes to several years and horizontal space scales from hundreds of metres to several thousands of kilometres. This research included studies in physical, chemical, and biological oceanography. Zooplankton studies focussed on the following:

\section{Quantitative aspects}

- 2-D seasonal patterns

- continental shelf wave patterns

- patterns influenced by submarine cañons

- conditions of boundary (upwelling) area versus that of central gyre area

- extension of upwelling effects

- effect of an average upwelling event,

- 3-D seasonal patterns and

- net growth rates

- links to fishery
Arndt \& Brenning, 1977

Postel, 1982

Postel, 1987

Kaiser \& Postel, 1978

Postel, 1985

Postel, 1990

Weiß \& Postel, 1991

Metabolic aspects

- feeding activity of Branchiostoma senegalense

- growth of Branchiostoma senegalense

- metabolic activity in relation to ROSSBY wave patterns and cyanobacteria distribution
Gosselck et al., 1978

Gosselck \& Spittler, 1979

Hernández-León et al., 1992

Taxonomic and ecological aspects

- chaetognaths

- thaliaceans.

- calanoids

- Branchiostoma larvae
Köller et al., 1976

Arndt \& Köller, 1977

Arndt \& Wranik, 1977

Wranik \& Arndt, 1978

Brenning \& Fadschild, 1979

Brenning, 1980, 1981a, b, 1982a, b, 1983, 1984, 1985a, b, 1986

Chagouri, 1989

Gosselck, 1975

Gosselck \& Kühner, 1973

Gosselck \& Hagen, 1973

Flood et al., 1978, 1982 


\section{Parasitological aspects}

Reimer et al., 1975

Reimer, 1977

The two aims of this paper are to draw attention to these unique data sets and to arouse interest in such areas again, where ecosystem development can be observed from an early to an equilibrium stage with all the ecological consequences over relatively short distances.

\section{MATERIAL AND METHODS}

In the 'seventies, large scale observations were carried out in the upwelling area off the coast of Northwest Africa (NWA), between Bahía de Garnet $\left(25^{\circ} \mathrm{N}\right)$ and Cabo Roxo $\left(10^{\circ} \mathrm{N}\right)$, from the near coastal area to the $21^{\circ} \mathrm{W}$ meridian. Further studies were performed on a section along the $30^{\circ} \mathrm{W}$ meridian, from $2^{\circ} \mathrm{S}$ to $15^{\circ} \mathrm{N}$, a reference area in comparison to the coastal zone without Ekman upwelling and with ecological equilibrium conditions (Fig. 1). In 1989 an area was investigated between $32^{\circ} \mathrm{N}$ and $10^{\circ} \mathrm{N}$, from the Middle Atlantic Ridge to about $21^{\circ} \mathrm{W}$, to study the transition between the boundary part of the North Atlantic Central Gyre, which is influenced by coastal upwelling, and its centre. Mesoscale upwelling processes were studied, mostly off Cape Blanc/Cape Barbas, off Nouakchott (NWA) and off Southwest Africa (SWA) at $21^{\circ} \mathrm{S}$, in the Namibian region (Fig. 1). A limited number of small scale studies were carried out off Cape Blanc (NWA).

Samples were collected, mostly in four depth ranges, from 200 to $0 \mathrm{~m}$, from 200 to

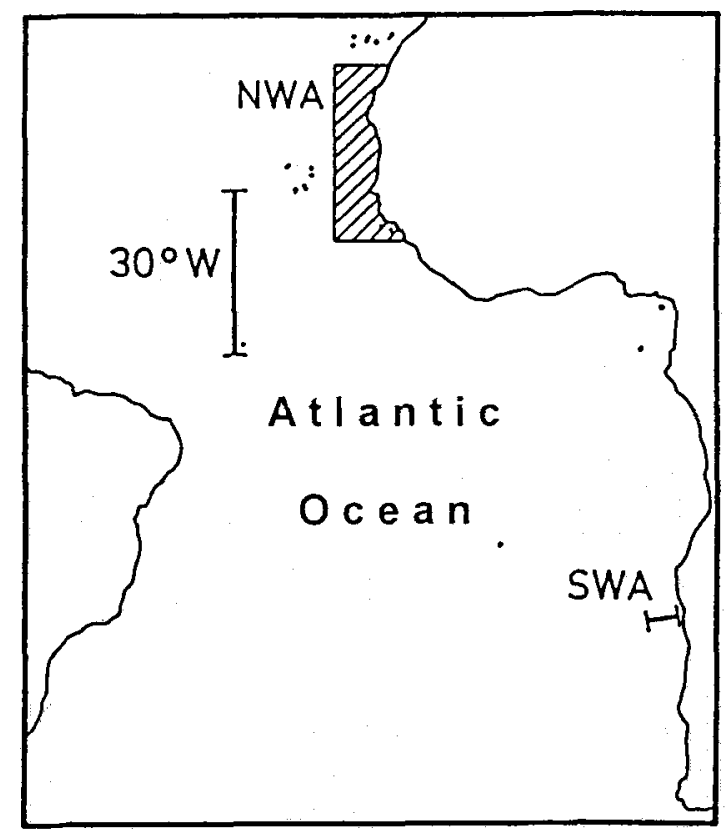

Fig. 1. Areas studied by R.V. "A. v. Humboldt" in the Atlantic Ocean: a large, seasonal study site off Northwest Africa (NWA), a reference area at $30^{\circ} \mathrm{W}$ without Ekman upwelling, and a mesocale transect off Namibia (SWA) 
$75 \mathrm{~m}$; from 75 to $25 \mathrm{~m}$; and from 25 to the sea surface, using the WP-2-net, which is recommended by UNESCO (Tranter, 1968). According to this author, this equipment quantitatively retains plankton between 0.2 to $10 \mathrm{~mm}$ size.

On the basis of various literature sources and data, it was estimated by Postel (1990) that plankton of this size range represents (in terms of dry mass) about one third of the total plankton in the euphotic zone of an upwelling area. This part consists of almost similar proportions of fine filter feeders (like meroplankton, appendicularians, doliolids, and small calanoids), of coarse filter feeders (e.g. medium-sized calanoids, and juvenile euphausids), and of predators (like cyclopoids, large calanoids, coelenterates, and polychaetes). Their developmental times range from 25 to 40 days. This plankton fraction is of nutritive relevance for fishes of commercial value, like Scomber colias $(70 \%)$, Trachurus sp. $(60 \%)$ and Sardinella sp. $(50 \%)$.

Dry mass was determined according to Lovegrove (1966). During different cruises, slight modifications in the field and in the laboratory procedures occurred, which sometimes caused remarkable influence on the data. The sum of methodical errors produced underestimations of 15 to $65 \%$, which were considered during a data validation procedure. The largest overestimation was represented by $21 \%$ from using wire length instead of flow meters to calculate the filtrated water volume. Losses of about $48 \%$ occurred when samples were frozen before oven drying (Postel, 1990).

For details of the taxonomic identification procedures, the reader is referred to the publications mentioned above under taxonomical and ecological aspects.

\section{RESULTS AND DISCUSSION}

\section{Ecological consequences of an average coastal upwelling event}

The results originate from a programme off Namibia which lasted three weeks during the upwelling season in October 1979. It consisted of a transect, perpendicular to the coast, from $30 \mathrm{~km}$ to $170 \mathrm{~km}$. The distance between the stations was $10 \mathrm{~km}$, the measurements were carried out every 1.5 days. Figure 2 presents the geographical situation (2a), and the successive progress of ecosystem development from the near shore upwelling centre to offshore conditions ( $2 \mathrm{~b}$ to $2 \mathrm{~m}$ ) in terms of averages of 15 measurements. The diagrams should be studied from the right, the African coast line, to the left.

The sea level increases, indicating that winds favourable for upwelling shift the near shore surface water in an offshore direction $(2 \mathrm{~b})$. Cold, low saline, oxygen poor, and nutrient rich water from deeper layers replaces it $(2 \mathrm{c}$ to $2 \mathrm{~g}$ ). With increasing distance to the upwelling centre, temperature rises by solar radiation and the salinity increases by evaporation. Oxygen content starts to increase and successively to decrease due to changing importance of the balance between primary production and respiration losses. Nutrients are affected in the same manner. Chlorophyll-a content as indicator for phytoplankton biomass reaches a maximum at about $30 \mathrm{~km}$ down stream of the upwelling site $(2 \mathrm{~h})$. With increasing distance to the shore the ecosystem is increasingly stabilized. The decreasing dominance index in conjunction with the increasing diversity index is an indication of this phenomenon $(2 \mathrm{l} ; 2 \mathrm{~m})$ in the same way as the number of zooplankton groups, which increases from 16 at $30 \mathrm{~km}$ to 25 at $170 \mathrm{~km}$ offshore. The development of the mean abundances in the dominant taxonomic groups underline this 
ecosystem zonation: the optimum of nauplia is followed by the small and by the medium sized calanoids farther offshore, and is finally followed by the thaliaceans, a group which is dominant far away from the upwelling centre $(2 \mathrm{k})$. The zooplankton dry mass pattern in two depth levels on transects perpendicular to the coast $\left(2 i_{i} 2 \mathrm{j}\right)$ corresponds with the calanoid abundances in Figure $2 \mathrm{k}$. The highest values of biomass and abundances were encountered between 130 and $160 \mathrm{~km}$ offshore.

Offshore transport velocity was estimated in three different ways in the upper $60 \mathrm{~m}$ (Ekman layer), based on wind drift, current measurements, and the calculated development rates of copepods, which are temperature related. The results showed that a distance of ten kilometres was covered within two days. All these data led to the conclusion, that the maximum of phytoplankton biomass occurred in about two days, and that of copepods between 20 and 23 days after an upwelling event.

The doubling of zooplankton biomass after a single mean upwelling event is remarkable. This can also be observed in the following example, where a measuring approach was used, which was designed very differently.

\section{Seasonal patterns}

Seven cruises were carried out during different seasons off NWA between $25^{\circ} \mathrm{N}$ and $10^{\circ} \mathrm{N}$ on 7 transects which were perpendicular to the coast up to about $21^{\circ} \mathrm{W}$ (Fig. 3);

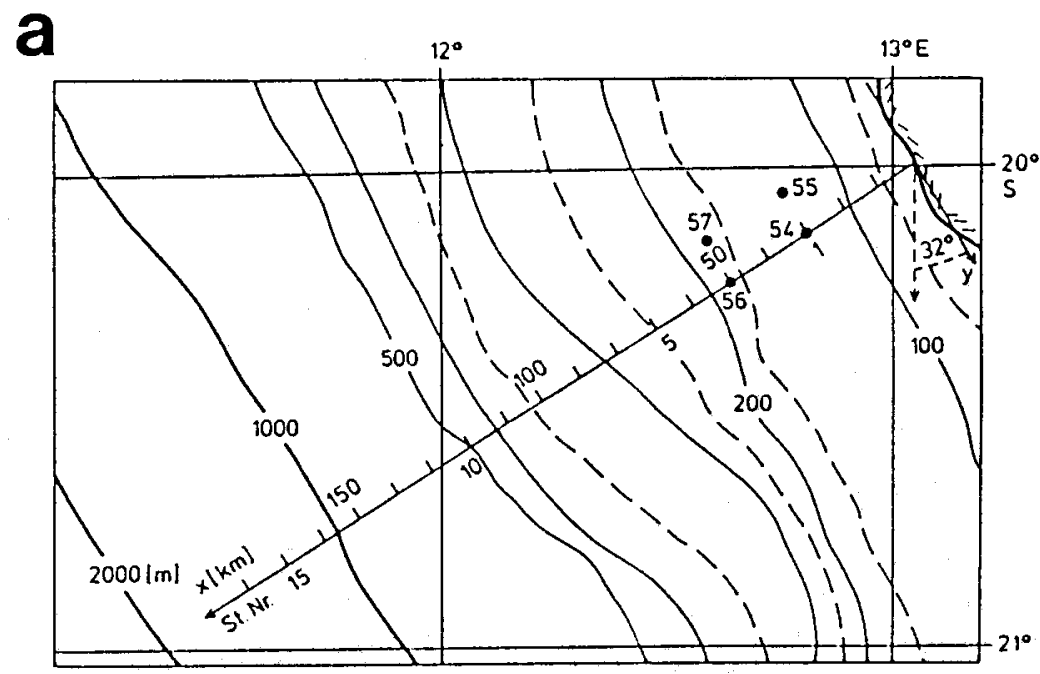

Fig. 2. Position of the cross-shelf measuring profile, which was repeated every 36 hours from October 16 th to November 11th 1979 off Dune Point, Namibia (2a), and the temporal averaged cross-shore distribution (including confidence ranges, $p<0.05$ ) of the sea level difference between the sea surface and the $100 \mathrm{~m}$ reference plane (2b), the temperature (2c) and salinity (2d), the oxygen- (2e), phosphate- (2f), silicate- (2g), and chlorophyll-a-concentration (2h) at the sea surface, the zooplankton dry mass in the upper $30 \mathrm{~m}(2 \mathrm{i})$, the zooplankton dry mass between 30 and $75 \mathrm{~m}$ depth (2j), the zooplankton abundance (2k), the dominance index, according to Simpson (1949), cited by Odum (1980) (21), and diversity index, according to Shannon \& Weaver (1949), cited by Odum (1980), for meso-zooplankton in the upper $30 \mathrm{~m},(2 \mathrm{~m})$; (Hagen et al., 1981; Postel, 1990) 

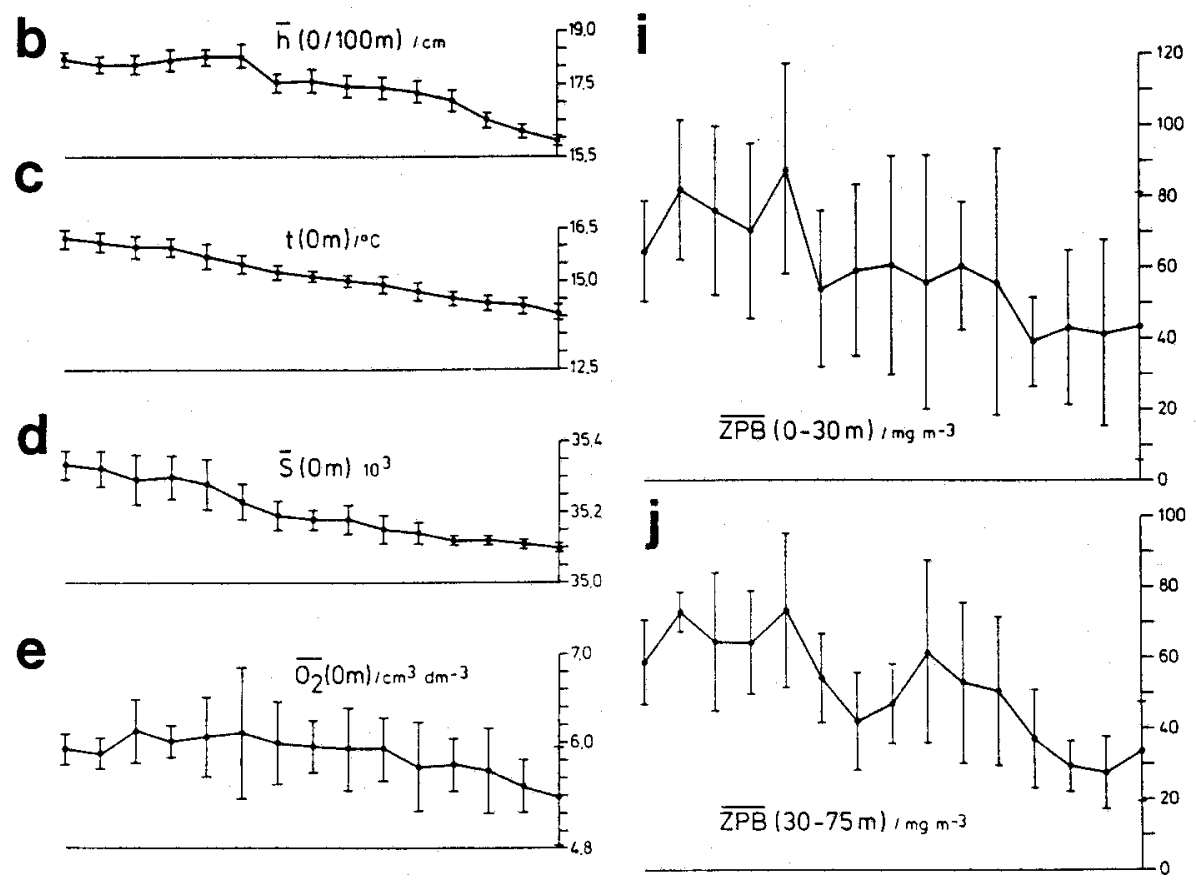

e
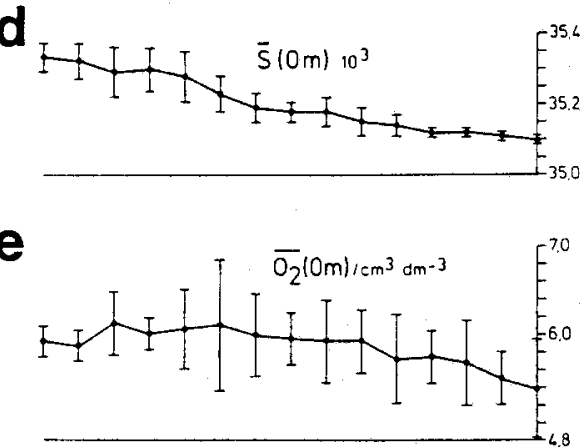

f

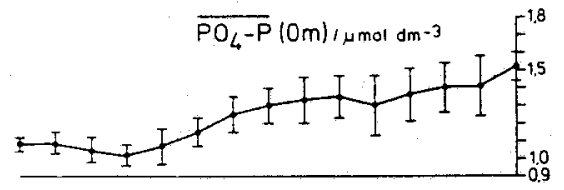

k

g

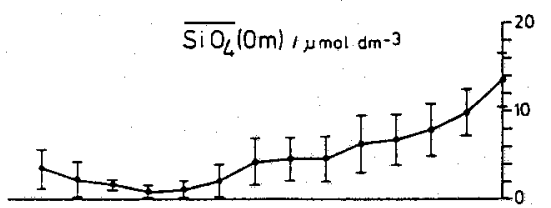

h $\overline{C h l .0}(0 \mathrm{~m}) / \mathrm{mg} \mathrm{m}^{-3}$
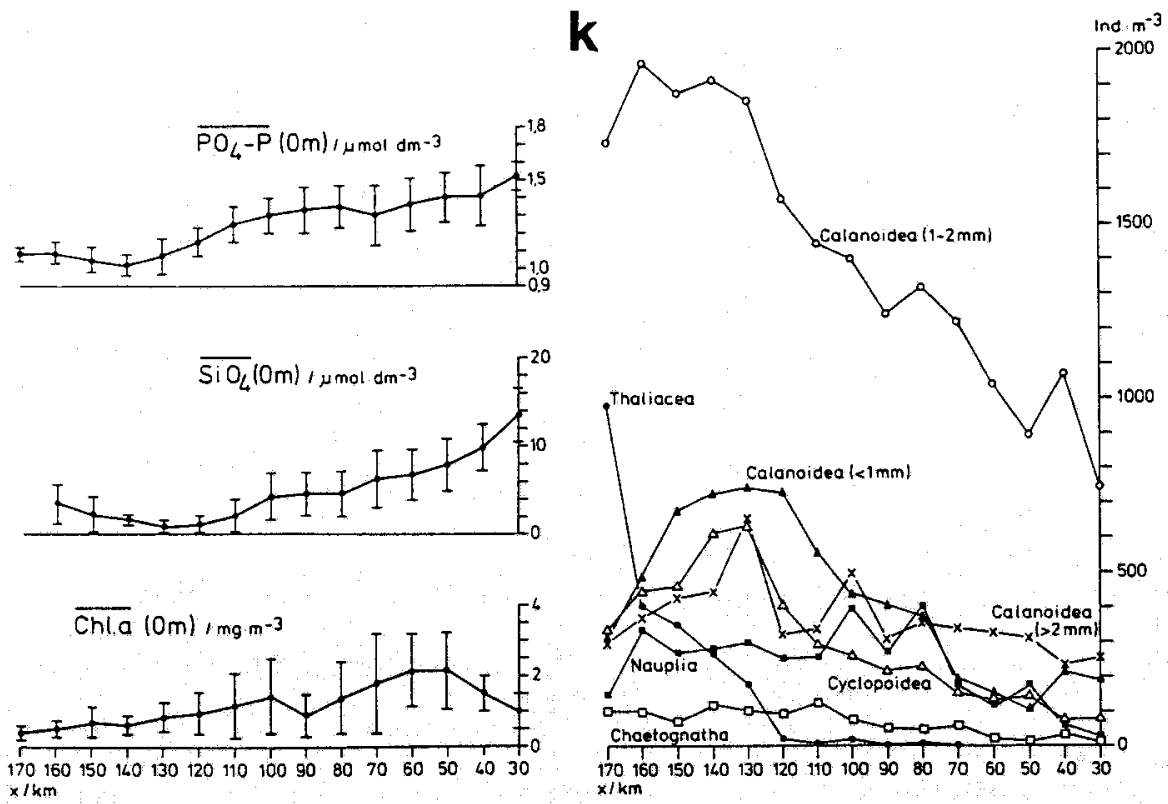


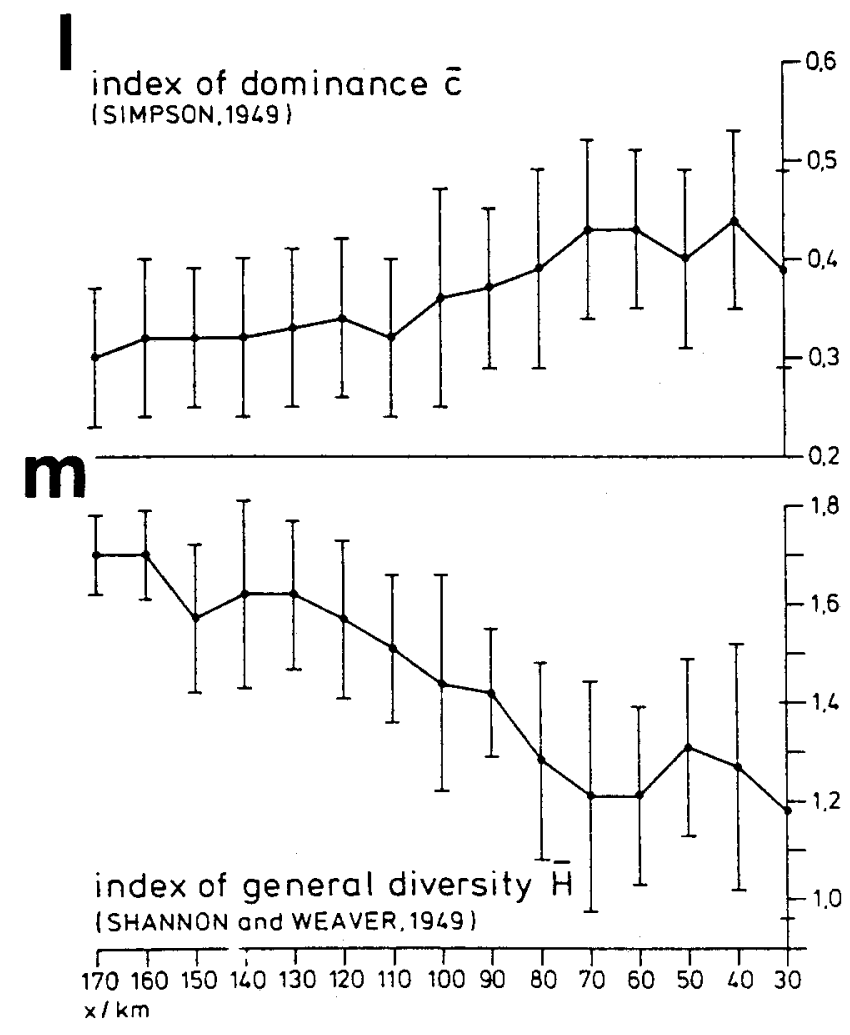

observations were done in different years of similar upwelling intensities (Arfi, 1985). The amount of data was sufficient to carry out the seasonal analysis on the basis of mean values obtained over the shelf, the shelf break, and the offshore area, from the sea surface down to the bottom or to a maximum depth of $200 \mathrm{~m}$. In the latter region, vertical subdivisions into the upper $25 \mathrm{~m}$ layer, the intermediate one down to $75 \mathrm{~m}$, and a sublayer from 75 to $200 \mathrm{~m}$, were possible (Postel, 1990).

To find the typical zooplankton biomass response to upwelling, the seasonal course of the sea surface temperature difference between near coastal stations and the offshore area, calculated by Speth et al. (1978), was compared with the zooplankton pattern. The situation off the shelf break in the upper $200 \mathrm{~m}$ is shown as an example in Figure 4. Coincidence of physical and zooplankton patterns was observed south of $23^{\circ} \mathrm{N}$. Around $20^{\circ} \mathrm{N}$, upwelling and a correspondent higher biomass is pronounced all the year round. South of it, a negative deviation of sea surface temperature and a higher zooplankton biomass are recorded during the first half of the year. A similar relationship, but with opposite sign, also holds for the second half of the year. In the offshore region, north of $23^{\circ}$ $\mathrm{N}$, upwelling was not reflected in the changes of zooplankton biomass, because nutrient poor North Atlantic Central Water (NACW) prevails in the upwelling source water, instead of the nutrient rich South Atlantic Central Water (SACW). 


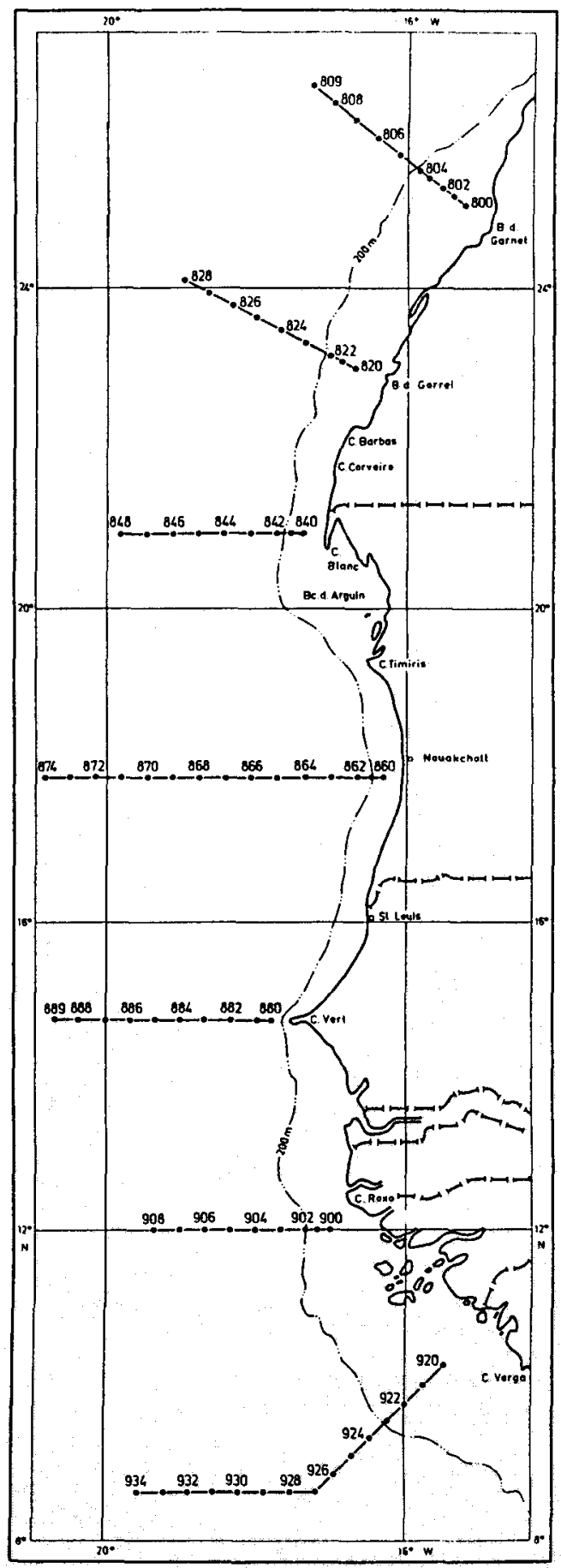

Fig. 3. Standard profiles off Northwest Africa, where zooplankton was sampled in August/September 1970, October/November 1970, June/July 1972, December 1972/January 1973, February/ March 1973, May 1975, and partly in February 1976 
$\overline{\overline{\mathrm{PB}}}(0-200 \mathrm{~m}) / \mathrm{mg} \cdot \mathrm{m}^{-3} \mathrm{H}>200 \mathrm{~m}$

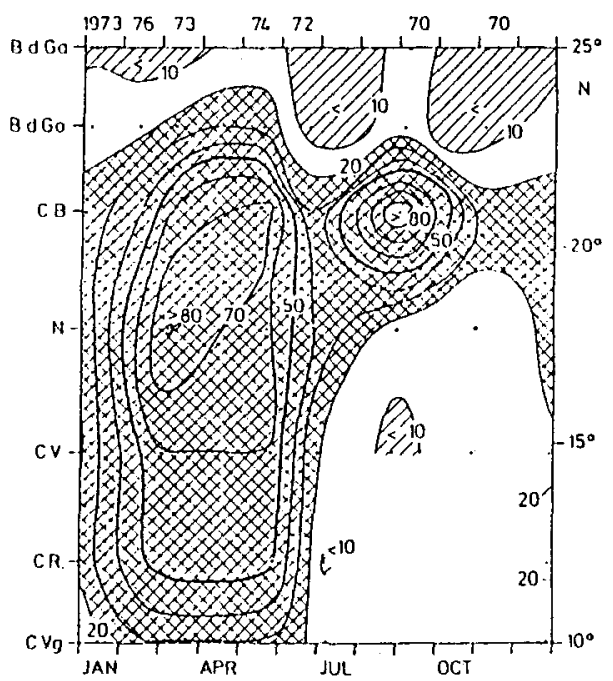

$\Delta$ SST coast / offshore

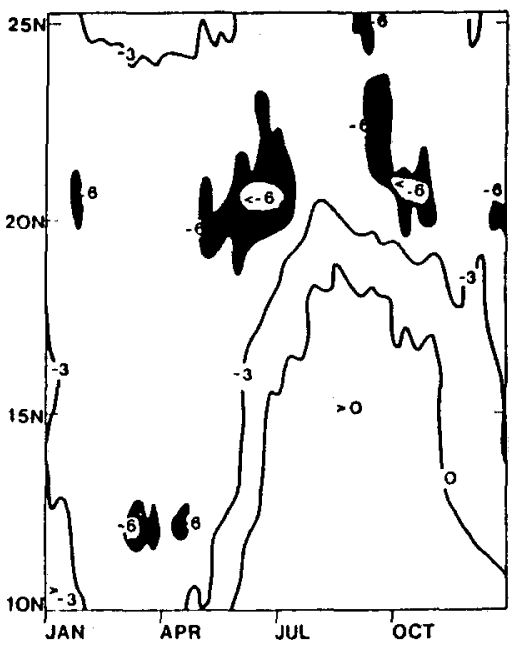

Fig. 4. Mean zooplankton biomass density in the $200 \mathrm{~m}$ surface layer of the oceanic region off Northwest Africa (water depth $>200 \mathrm{~m}$, longitude $<20^{\circ} \mathrm{W}$ ) as a function of latitude and season, in comparison with the seasonal variation in the difference of sea surface temperature of the same latitude $(\Delta \mathrm{SST} / \mathrm{K})$ between the central Atlantic and coastal regions, averaged between 1969 and 1976 (after Speth et al., 1978)

The zooplankton dry mass pattern in Figure 4, which corresponds with the upwelling indicated by the pattern of temperature differences at the surface, is bounded by the $20 \mathrm{mg} \cdot \mathrm{m}^{-3}$ isoline. The mean dry mass in the upper $200 \mathrm{~m}$ of the reference area at $30^{\circ} \mathrm{W}$ (Fig. 1), which is free of upwelling, is $10 \mathrm{mg} \cdot \mathrm{m}^{-3}$. The comparison shows that the doubling of biomass is the typical response to a single upwelling event. This is in accordance with the observation off Namibia (see above). The same holds true for the different strata - above $25 \mathrm{~m}$, between 25 and $75 \mathrm{~m}$. and from 75 to $200 \mathrm{~m}$. The seasonal signal is strongest offshore.

In addition to the developmental time of the mesozooplankton, which lasts 20 to 23 days in the upper $75 \mathrm{~m}$ after an upwelling event off Namibia, an upwelling response of 6 to 8 weeks is observed in depths greater than $75 \mathrm{~m}$ off NWA (Postel, 1990).

A significant relationship was observed between the duration of seasonal upwelling (that means the numbers of single upwelling events with typical time scales of about two weeks) and the cumulative increase of biomass in the near coastal area, the shelf break and the offshore region (Fig. 5). This relationship reflects the net growth rate of zooplankton biomass, which is most pronounced at the shelf break (Fig. 5b), the area with the largest fish biomass, and in the upper $25 \mathrm{~m}$ (Fig. 5a), according to Postel (1990). Differences of the expected and the real rate values in conjunction with the known amount of nutritive demands of fishes allow the estimation of the fish biomass in a given area (Weiß \& Postel, 1991).

When the typical "response" biomass of the upper $25 \mathrm{~m}$ is taken as the basis, the 

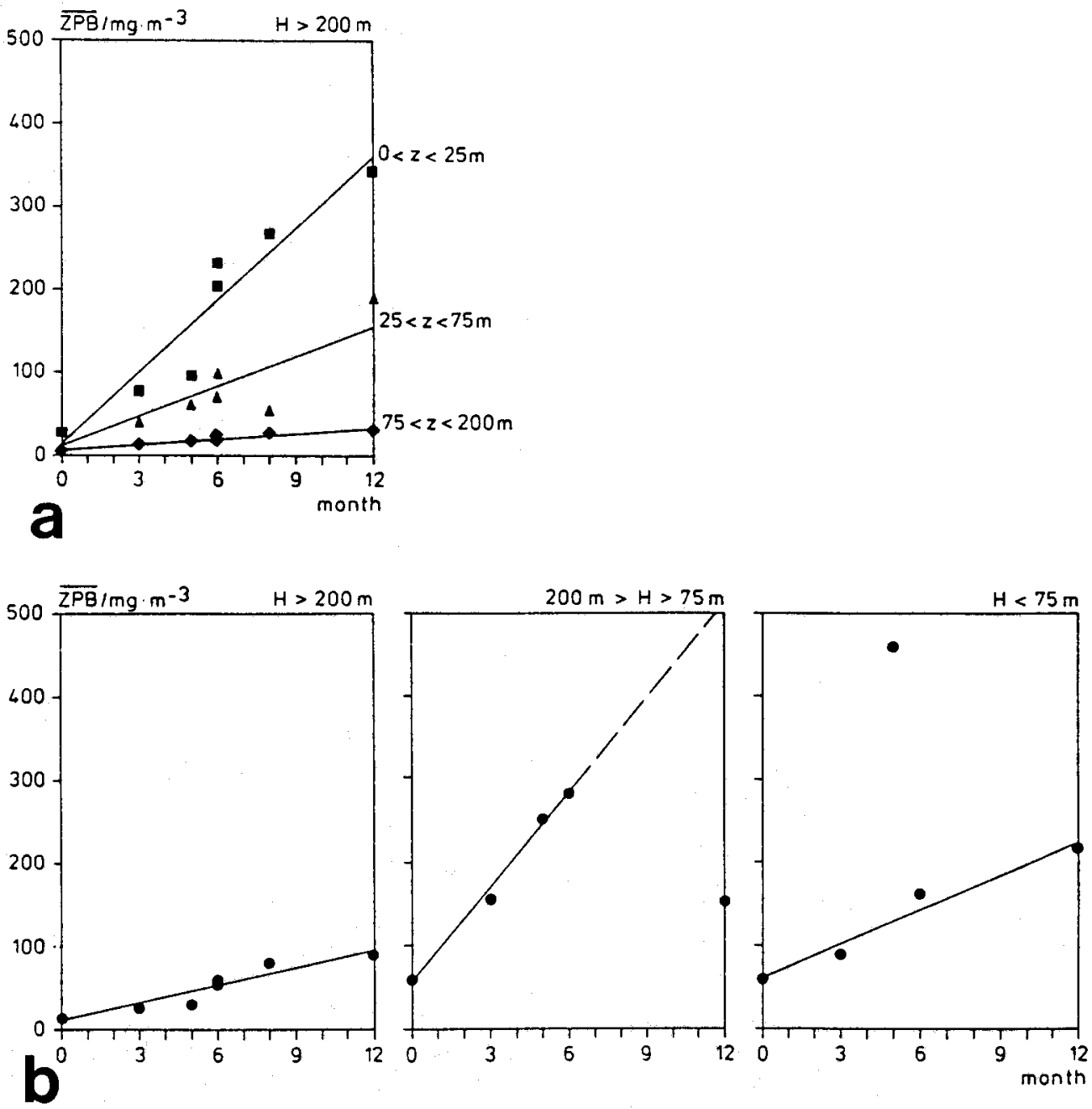

Fig. 5. Relationship between the duration of upwelling season (months) and the highest zooplankton dry mass during this time $\left(\mathrm{mg} \cdot \mathrm{m}^{-3}\right)$ due to a cumulative biomass increase from event to event, in the upper $200 \mathrm{~m}$

5a: in the three defined sublayers of the $200 \mathrm{~m}$ surface layer in the oceanic region (water depth $\mathrm{H}$ $>200 \mathrm{~m}$ ):

5b: separately for the whole layer down to a depth of $200 \mathrm{~m}$ in the oceanic $(\mathrm{H}>200 \mathrm{~m})$, shelf edge $(200>\mathrm{H}>75 \mathrm{~m})$, and near shore regions $(\mathrm{H}<75 \mathrm{~m})$

seasonal extension of the area, influenced by coastal upwelling, was largest in the first half of the year, from $10^{\circ} \mathrm{N}$ to $24^{\circ} \mathrm{N}$, more than $400 \mathrm{~km}$ offshore and down to a depth of more than $200 \mathrm{~m}$. It shrinks in the second half of the year to an area between $20^{\circ} \mathrm{N}$ and $22^{\circ} \mathrm{N}$, with a coastal distance of 100 to $200 \mathrm{~km}$ and a mean depth of $25 \mathrm{~m}$ (Postel, 1990). 


\section{Mesoscale disturbances}

\section{Eddies}

The area between $18^{\circ} \mathrm{N}$ and $22^{\circ} \mathrm{N}$ off NWA is a region with a high potential eddy energy (Dantzler, 1977). Here, the variability of large scale zooplankton patterns is remarkable throughout the year (Postel, 1990). Eddies with diameters of several tens of
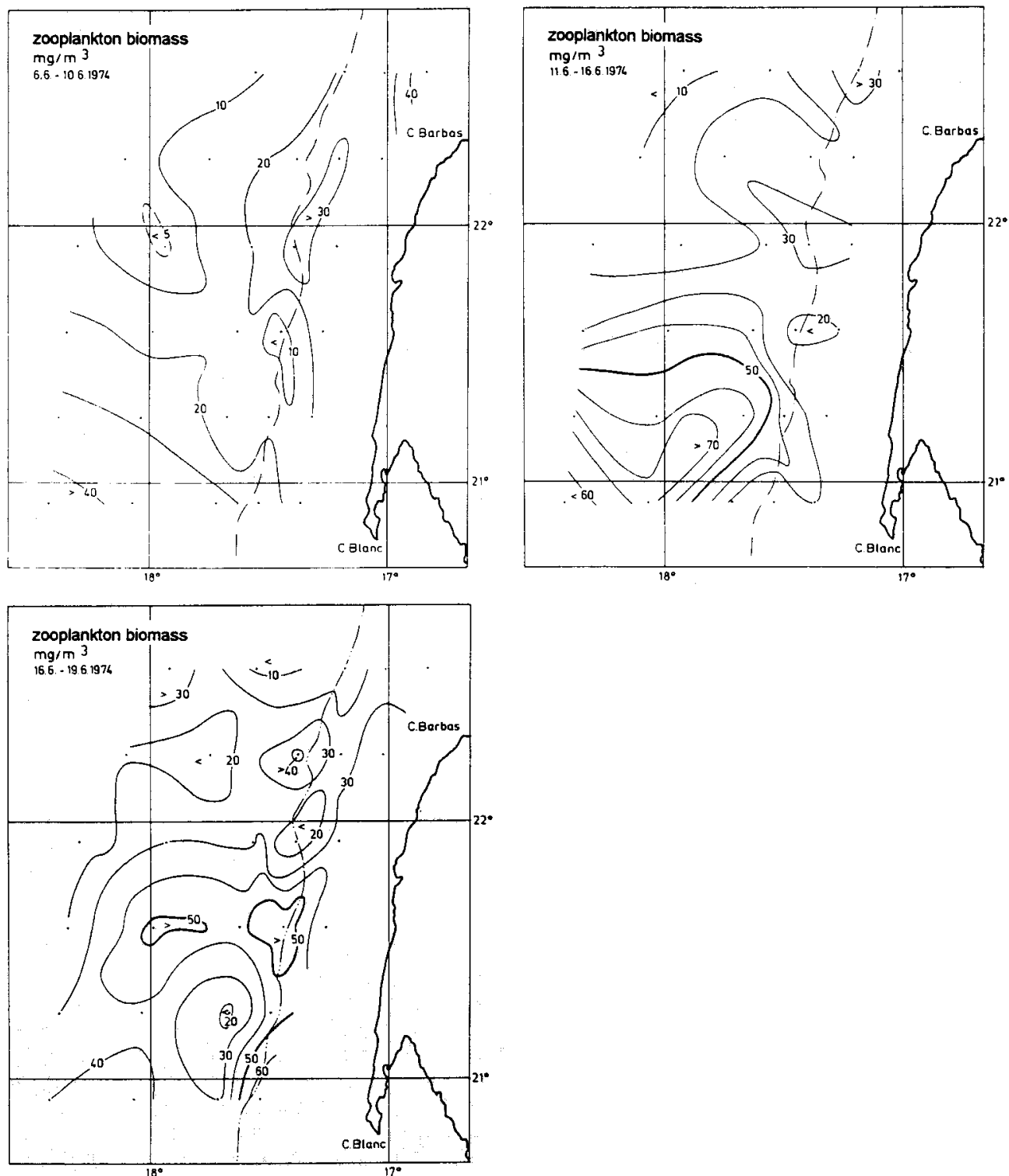

Fig. 6. Zooplankton biomass during three eddy resolving plankton surveys, conducted between Cap Barbas and Cap Blanc (Northwest Africa) every five days during June 1974 
kilometres were observed during some weeks (Tomzcak; 1973; Hagen, 1977). To record this phenomenon, mesoscale studies were carried out in this area. A grid was used with distances between the stations from $18 \mathrm{~km}$ to $37 \mathrm{~km}$ (Fig. 6). The extensions of the grid were about $100 \times 200 \mathrm{~km}$. Samples were collected in the upper $25 \mathrm{~m}$ every third day at the same position. The mean biomass during the total sampling period was about $30 \mathrm{mg}$. $\mathrm{m}^{-3}$. A zooplankton patch with a dry biomass larger than the average was shifted from southwest to northeast during the period under investigation. It correlates with a cyclonic eddy. In its centre, a lower biomass was observed, which can indicate new upwelled water. The physical structure is described by Schemainda \& Schulz (1976).

\section{Continental shelf waves}

Figure 7 shows examples of temporal and spatial-temporal variability of oceanographical properties, especially zooplankton dry mass, with typical time scales of several days, caused by long coastal parallel waves, propagating poleward at the shelf edge. The hydrographical background is described by Mysak (1980), Hagen et al. (1981) and others.

Figure $7 \mathrm{a}$ presents a time series of 11 days duration with plankton catches every 3 hours in the upper $30 \mathrm{~m}$ layer, carried out on the shelf off Namibia in November 1976. The dotted line indicates a 5.5 days co-sinus oscillation to illustrate the most pronounced period.

Figure $7 \mathrm{~b}$ demonstrates the entropy spectrum of the same time series. The spectral analysis method separates the total variability into single contributing amounts. Peaks of energy density are signs of significant patterns. In Figure $7 \mathrm{~b}$ the highest amount is in the range of 5 or more days, which corresponds to the period scale of continental shelf waves, (cf. Postel, 1982). The reason for their influence on zooplankton biomass might be the vertical transport velocity, which is orientated to the surface in the crest of the wave (upwelling) and vice versa, in connection with vertical differences of plankton concentrations and always the same sampling depth.

Figure $7 \mathrm{c}$ shows the spatial-temporal pattern of zooplankton biomass residuums in the layer between 30 and $75 \mathrm{~m}$. Residuums were calculated by subtraction of a trend from

Fig. 7. Examples of significant zooplankton dry mass variability in the time range of several days detected off Namibia:

7a: during a time series of 11 days duration on the shelf off Namibia in November 1976 with plankton catches every 3 hours in the upper $30 \mathrm{~m}$ layer;

$7 \mathrm{~b}$ : in the spectral energy density, estimated according the Maximum Entropy method, of the same time series, in energy units; $v[\mathrm{cph}]$ means frequence in cycles per hour, T means period, $=1 / v$; (according to Postel, 1982);

$7 \mathrm{c}$ : in the spatial-temporal pattern of zooplankton biomass residuums in the layer between 30 and $75 \mathrm{~m}$. The measurements were carried out between $30 \mathrm{~km}$ and $170 \mathrm{~km}$ on a transect which was perpendicular to the Namibian coast every 1.5 day in October 1979 (Fig. 2a). Residuums were calculated by subtraction of a trend from the original data ( see text). Hatched areas indicate the positive anomaly;

$7 \mathrm{~d}$ : in comparison to the course of the residuums of temperature at the bottom of the Ekman layer, the sea level difference between the sea surface and the $600 \mathrm{~m}$ reference level, the zooplankton dry mass between 30 and $75 \mathrm{~m}$ of the hourly catch effort of fishing vessels in the area, and the 5 days cosinus oscillation, which illustrates the most pronounced variability period; according to Hagen et al.

(1981) 

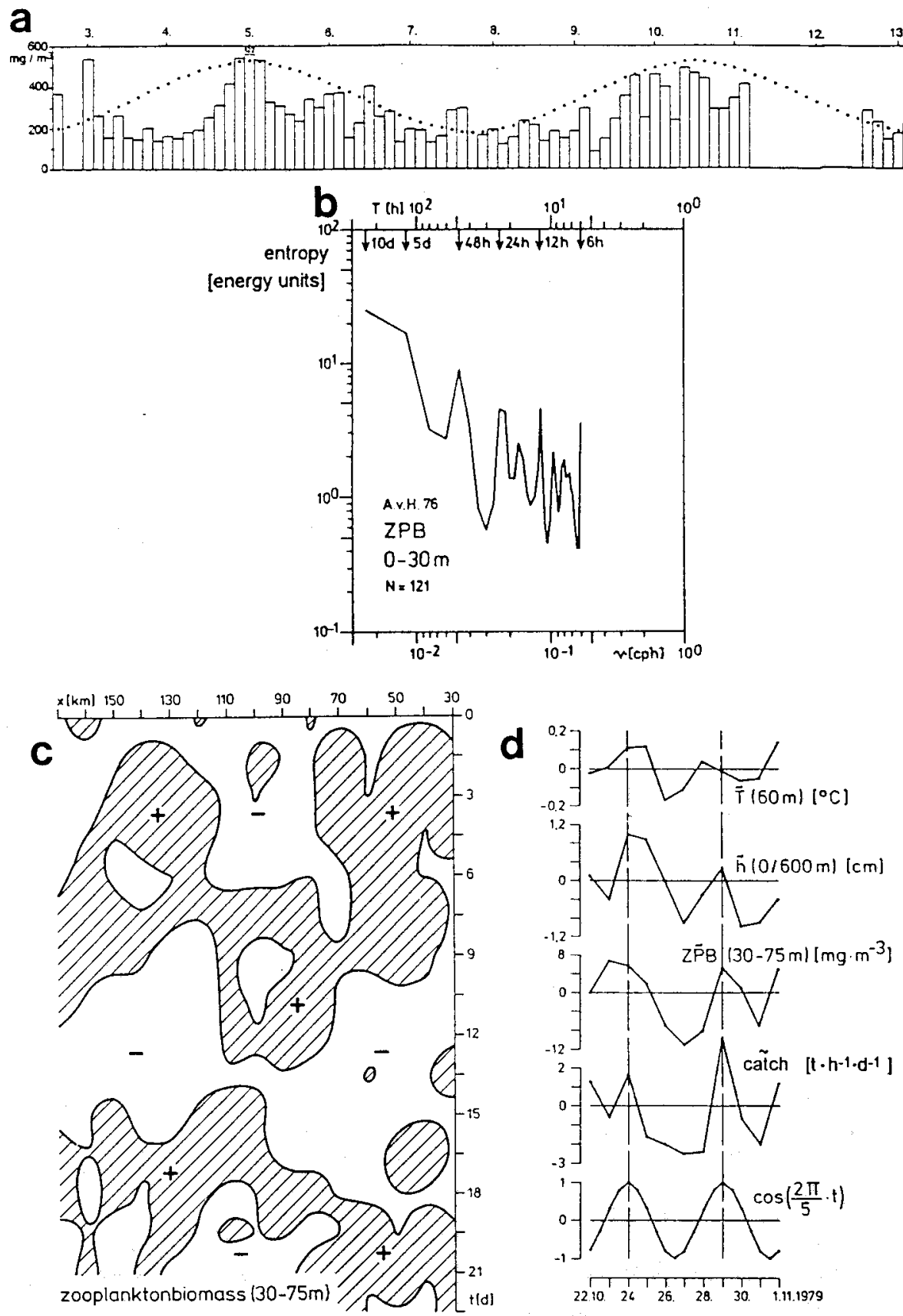
the original data. Trend estimation was done by linear regression between the actual biomass data and the distance to the coast. The hatched area represents the positive anomaly. The measurements were carried out every 36 hours, between $30 \mathrm{~km}$ and 170 $\mathrm{km}$ on a transect which was perpendicular to the Namibian coast, from an upwelling centre to offshore conditions, in October 1979 (Fig. 2a). The trend of these data includes mainly the signal of ecosystem succession downstream of the upwelling centre. The residual biomass pattern is superimposed on it. This pattern is another example of the influence of long coastal parallel waves on zooplankton concentrations, resolved in time and space. The "chess-board like" structure in Figure 7c is the proof of such a relationship (cf. Hagen et al., 1981).

The influence of continental shelf waves on patterns of oceanographic properties is additionally underlined by Figure $7 \mathrm{~d}$. Here the de-trended course of the sea level difference between the sea surface and the $600 \mathrm{~m}$ reference level (h $[0 / 600 \mathrm{~m}])$, caused by continental shelf waves, correlates with temperature anomalies $T(60 \mathrm{~m})$. Cold water means more intense upwelling. Both patterns coincide with the zooplankton biomass deviation (from the long scale trend) and that of the hourly catch effort of fishermen. The co-sinus oscillations illustrate the dominant 5 day period. The results in Figure $7 \mathrm{~d}$ are based on the same programme described above (Fig. 2a and $7 \mathrm{c}$ ). The data are also residuals of a linear trend. Such a trend might be caused by hydrographic features, with scales, which are larger than that, produced by continental shelf waves. It was determined by linear regression against time, using the data, which were averaged over the first $30 \mathrm{~km}$.

\section{Water masses}

Water masses are distinguished by different characteristics. From the physical point of view, salinity and temperature are the most usual parameters (Sverdrup et al., 1942; Tomczak \& Hughes, 1980; Wolf \& Kaiser, 1978). In the case of upwelling research, the nutrient content is a further suitable tool for classification (e.g. Tomczak \& Large, 1989; Klein, 1992). To search for indicator species is the methodological tool of biologists. Köller $\&$ Arndt (in prep.) tried to use chaetognaths for that purpose. They found that different species combinations, and sometimes the absence of one or more species, indicate different water masses (Table 1). So the lack of Sagitta regularis shows nutrient-poor NACW in general. Additional differences in species combinations subdivide surface and upwelled NACW. Further results with respect to upwelled SACW, tropical surface water, and tropical coastal water are given in Table 1, which also includes a rough distributional map of these dominant water masses, typical for the second half of the year.

Figure 8 shows the abundance of two calanoids in the temperature salinity diagram. Calanus helgolandicus (Claus, 1863), a typical species of the North Atlantic, is in the salinity range of NACW, whereas Calanoides carinatus (Krøyer, 1849) indicates SACW (Brenning, 1980).

\section{Reproduction and maintenance of calanoids in near coastal areas}

Chagouri (1989) compared temperature-dependent developmental times of Calanus carinatus and transport velocities of water masses according to Hagen (1981) in the coastal current regime down to $200 \mathrm{~m}$ to prove maintenance mechanisms for these 
Table 1. Distribution of chaetognaths off Northwest Africa (ab. = abundance [ind. $\cdot \mathrm{m}^{-3}$ ], fre. $=$ frequency [\%]), according to Köller \& Arndt (in prep.); bold letters mean indicator species, absent species are listed in lowest part of table
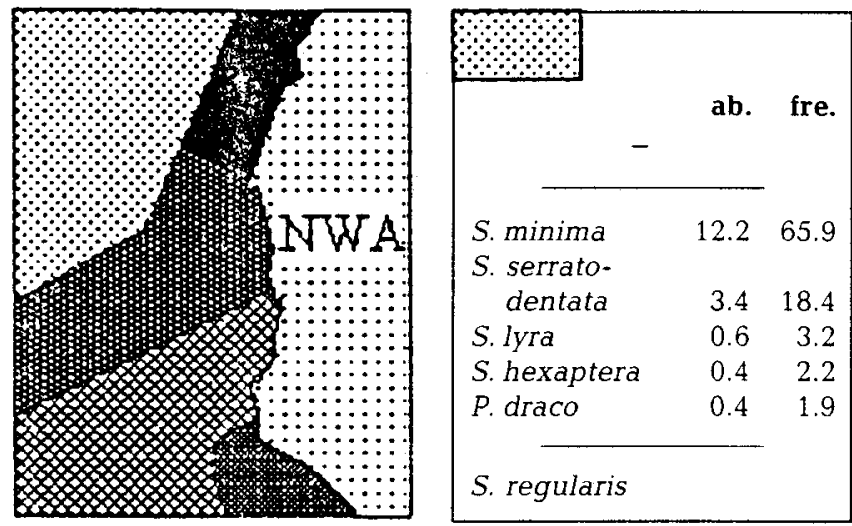

North Atlantic Central water (low nutrient level)

\begin{tabular}{|c|c|c|}
\hline \multicolumn{3}{|l|}{ 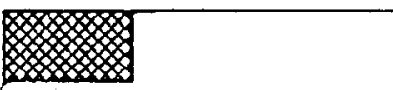 } \\
\hline S. enflata & $\begin{array}{l}\text { ab. } \\
5.8\end{array}$ & $\begin{array}{r}\text { fre. } \\
52.6\end{array}$ \\
\hline K. mutabbii & 0.4 & 3.6 \\
\hline S. enflata & 5.8 & 52.6 \\
\hline S. serrato- & & \\
\hline dentata & 1.8 & 16.3 \\
\hline S. subtilis & 0.9 & 7.8 \\
\hline S. hispida & 0.7 & 6.3 \\
\hline S. regularis & & \\
\hline S. tasmanica & & \\
\hline
\end{tabular}

tropical surface water (low nutrient level)

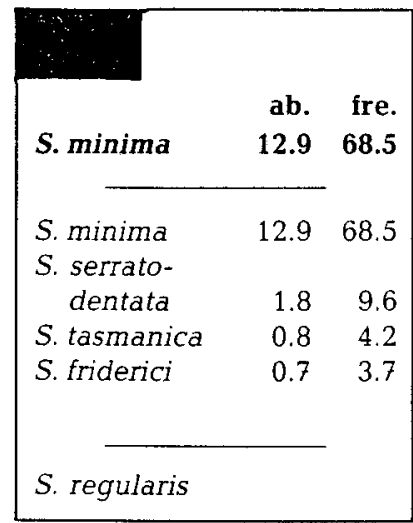

upwelled North Atlantic Central water (low nutrient level)

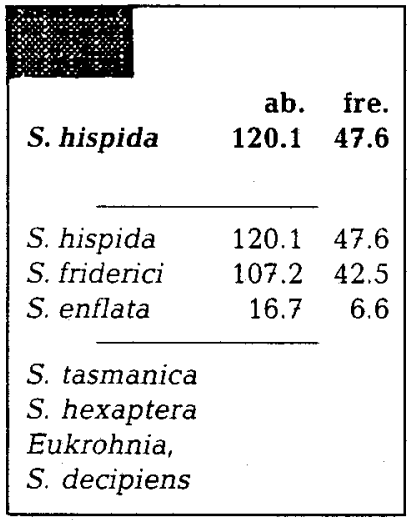

tropical coastal water (high nutrient level)

organisms in the near coastal ecosystem. Subsequently, she designed a diagram (Fig. 9). According to this, the development starts with nauplius stage $I$ in the fresh upwelled water of the near coastal zone and continues up to the copepodite IV stage just before reaching a downwelling area, which is connected to a coastal parallel front. Subsequent transport probably occurs by recirculation in less than $100 \mathrm{~m}$ depth. Animals will be also trapped by the coastal parallel undercurrent, the origin of upwelling water. The net result is a combination of zonal and meridional transport components, which are directed offshore and equatorwards and vice versa. The transport would last about 21 days, which corresponds with the above-mentioned, calculated developmental times for copepods off Namibia. A complete life cycle takes place in such a current regime, which can, therefore, 

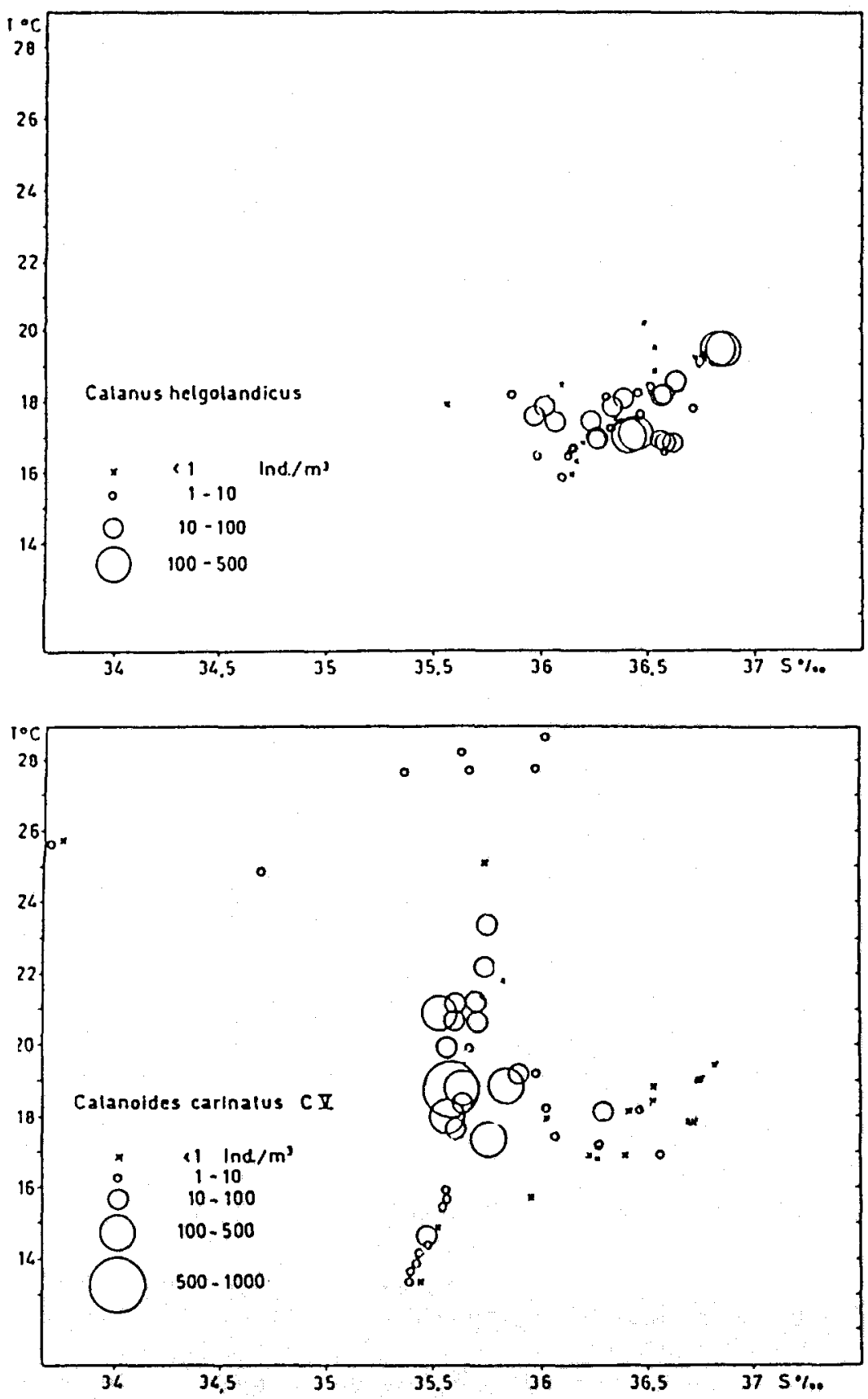

Fig. 8. Differences in the occurrence of Calanus helgolandicus (Claus, 1863) and Calanus carinatus (Krøyer, 1849) according to their temperature salinity demands (C V is copepodit stage V), according to Brenning (1980) 


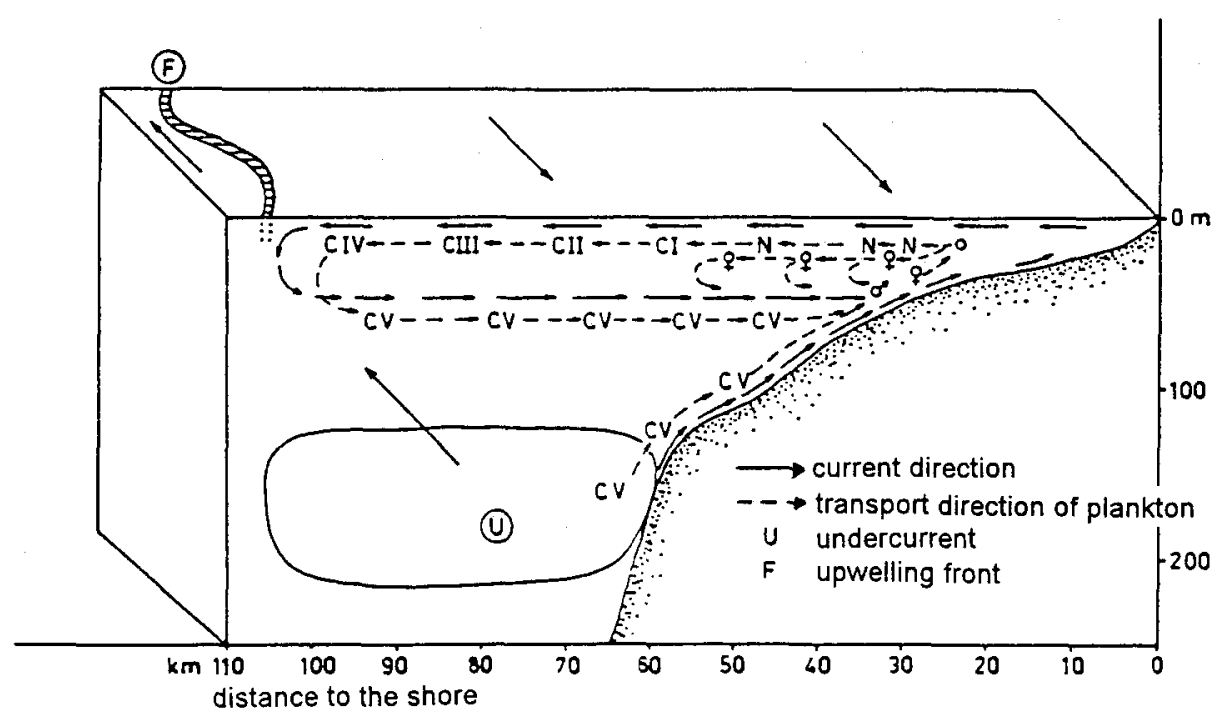

Fig. 9. Tentative diagram to demonstrate maintenance mechanisms of Calanus carinatus (Krøyer, 1849 ) in the near coastal area off Northwest Africa by a coupling mechanism of the development and current velocities in the system of main currents parallel and perpendicular to the coast according to Chagouri (1989)

be considered as a suitable maintenance mechanism for this taxonomical group in the near coastal area.

Acknowledgements. The paper is dedicated to the teacher of L. Postel, Dr. Alfred Schubert, who acted as Assistant for Oyster Research at Biologische Anstalt Helgoland 60 years ago. We are grateful to Dr. J. Alheit for linguistic corrections, and for the criticism of two anonymous experts.

\section{LITERATURE CITED}

Arndt, E. A. \& Brenning, U., 1977. The zooplankton biomass and its relation to abiotic and biotic factors in the upper $200 \mathrm{~m}$ of the upwelling region off North West Africa. - Wiss. Z. Univ. Rostock (Math.-nat. R.) 26 (2), 137-146.

Arndt, E. A. \& Köller, S., 1977. The taxonomy and ecology of the Chaetognaths in the epipelagial of the NWA upwelling region. - C.M./ICES, L:24, 1-4.

Arndt, E. A. \& Wranik, W. 1977. Studies on the taxonomy and distribution of Thaliaceans off NWA. C.M./ICES, L:23, 1-4.

Brenning, U., 1980. Zur Struktur und Dynamik von Calanoidenpopulationen (Crustacea, Copepoda) in den Aufquellgebieten vor Nordwest- und Südwestafrika. - Habil.Schr., Univ. Rostock, $394 \mathrm{pp}$.

Brenning, U., 1981a. Beiträge zur Calanoidenfauna (Crustacea, Copepoda) vor Nordwest- und Südwestafrika. I. Die Vertreter der Familie Calanoidae. - Wiss. Z. Univ. Rostock (Math.-nat. R.) $30(4 / 5), 1-12$.

Brenning, U., 1981b. Beiträge zur Calanoidenfauna (Crustacea, Copepoda) vor Nordwest- und Südwestafrika. II. Die Vertreter der Familie Eucalanidae. - Wiss. Z. Univ. Rostock (Math.-nat. R.) $30(4 / 5), 13-21$.

Brenning, U., 1982a. Beiträge zur Calanoidenfauna (Crustacea, Copepoda) vor Nordwest- und Südwestafrika. III. Die Vertreter der Familie Paracalanidae. - Wiss. Z. Univ. Rostock (Math.-nat. R.) 31 (6), 1-9. 
Brenning, U., 1982b. Beiträge zur Calanoidenfauna (Crustacea, Copepoda) vor Nordwest- und Südwestafrika. IV. Die Vertreter der Familie Pseudocalanidae. - Wiss. Z. Univ. Rostock (Math.nat. R.) 31 (6) 9-17.

Brenning, U., 1983. Beiträge zur Calanoidenfauna (Crustacea, Copepoda) vor Nordwest- und Südwestafrika. V. Die Vertreter der Familie Actiteidae. - Wiss. Z. Univ. Rostock (Math.-nat. R.) $32(5), 1-8$.

Brenning, U., 1984. Beiträge zur Calanoidenfauna (Crustacea, Copepoda) vor Nordwest- und Südwestafrika. VI. Die Vertreter der Familie Euchaetidae, Phaennidae und Scolecithricidae. Wiss. Z. Univ. Rostock (Math.-nat. R.) 33 (6), 1-9.

Brenning, U., 1985a. Beiträge zur Calanoidenfauna (Crustacea, Copepoda) vor Nordwest- und Südwestafrika. VII. Die Vertreter der Familie Centropagidae und Temoridea. - Wiss. Z. Univ. Rostock (Math,-nat. R.) 34 (6), 5-16.

Brenning, U., 1985b. Structure and development of Calanoid populations (Crustacea, Copepoda) in the upwelling regions off North and South West Africa. - Beitr. Meeresk. 52, 3-33.

Brenning, U., 1986. Beiträge zur Calanoidenfauna (Crustacea, Copepoda) vor Nordwest- und Südwestafrika. VIII. Die Vertreter der Familie Metridiidae, Lucicutiidae, Heterorhabdididae, Augaptilidae und Arietellidae. - Wiss. Z. Univ. Rostock (Math.-nat. R.) 35 (5), 5-16.

Brenning, U. \& Fadschild, K., 1979. Untersuchungen über die Calanoidenpopulation (Crustacea, Copepoda) auf einer Dauerstation vor Cap Blanc (NWA) im März 1973. - Wiss. Z. Univ. Rostock (Math.-nat. R.) 35 (6), 515-524.

Chagouri, G., 1989. Untersuchungen über den Zusammenhang zwischen Aufquellvorgängen und der Entwicklung von Calanus carinatus (Krøyer, 1849), (Copepoda, Calanoidea) im Seegebiet vor Nordwest-Afrika. - Diss., Univ. Rostock, 173 pp.

Dantzler, H. L., 1977. Potential energy maxima in the tropical and subtropical North Atlantic. - J. phys. Oceanogr. 7, 512-519.

Flood, P. R., Gosselck, F. \& Braun, J. G., 1982. Branchiostoma larvae in the upwelling area off Northwest Africa. - Rapp. P.-v. Réun. Cons. int. Explor. Mer 180, 307-314.

Gosseick, F., 1975. The distribution of Branchiostoma senegalense (Acrania, Branchiostomidae) in the offshore shelf region off North West Africa. - Int. Revue ges. Hydrobiol. 60, 199-207.

Gosselck, F. \& Hagen, E., 1973. Vorkommen und Verbreitung der Larven von Branchiostoma senegalense (Acrania, Branchiostomidae) vor NW Afrika. - Fisch.-Forsch. 11, 101-106.

Gosselck, F., Kell, V. \& Spittler, P., 1978. Feeding of Branchiostoma senegalense (Acrania, Branchiostomidae). - Mar. Biol. 46, 175-181.

Gosselck, F. \& Kühner, E., 1973. Investigations on the biology of Branchiostoma senegalense larvae off Nortwest African coast. - Mar. Biol. 22,67-73.

Gosselck, F. \& Spittler, P., 1979. Age structure, growth and weight of Branchiostoma senegalense (Acrania, Branchiostomidae) off NW Africa. - Int. Revue ges. Hydrobiol. 64, 541-550.

Hagen, E., 1977. Zur Problematik mesoskaler Verwirblungen in den Schelfgebieten des küstennahen Kaltwasserauftriebs. - Beitr. Meeresk. 39, 61-87.

Hagen, E., 1981. Mesoscale upwelling variations off the West African coast. In: Coastal and estuarine series 1. Coastal upwelling. Ed. by F. A. Richards. American Geophysical Union, Washington, 72-78.

Hagen, E., Schemainda, R., Micheichen, N., Postel, L., Schulz, S. \& Below, M., 1981. Zur küstensenkrechten Struktur des Kaltwasserauftriebs vor der Küste Namibias. - Geod. geophys. Veröff. (Reihe 4) 36, 1-99.

Hernández-León, S., Postel, L., Arístegui, J., Gómez, M., Montero, M., Torres, S., Almeida, C., Kühner, E., Brenning, U. \& Hagen, E., 1992. Large scale and mesoscale patterns of metabolic activity of epipelagic micro and mesoplankton in the northeastern Central Atlantic at $21^{\circ} \mathrm{N}$. C.M.ICES L:20, 1-11.

Kaiser, W. \& Postel, L., 1979. The importance of the vertical nutrient flux for the biological production in the Equatorial Undercurrent region at $30^{\circ}$ W. - Mar. Biol. 55, 23-27.

Klein, B., 1992. Die Kapverden - Frontalzone.-Ber. Inst. Meeresk., Kiel 227, 1-191.

Köller, S.; Breuel, G. \& Arndt, E. A., 1976. Untersuchungen zur geographischen Verbreitung und Ökologie der Chaetognathen vor Nordwestafrika unter besonderer Berücksichtigung ihrer Indikatorarten. - Wiss. Z. Univ. Rostock (Math.-nat. R.) 25 (3), 239-247.

Lovegrove, T., 1966. The determination of dry weight of plankton and the effect of various factors on 
Lovegrove, T., 1966. The determination of dry weight of plankton and the effect of various factors on the values obtained. In: Some contemporary studies in marine science. Ed. by H. Barnes. Allen \& Unwin, London, 462-467.

Postel, L., 1982. Mesoscale investigations on space-temporal variability of the zooplankton biomass in the upwelling regions off Northwest and Southwest Africa. - Rapp. P.-v. Réun. Cons. int. Explor. Mer 180, 274-279.

Postel, L., 1985. The pelagic cross-shelf and alongshore boundaries of the North West African upwelling region and their annual variability in terms of zooplankton biomass. In: Simposio internacional sobre áreas de afloramiento más importantes del $\mathrm{O}$ africano (Cabo Blunco y Benguela). Ed. by C. Bas, R. Margalef \& P. Rubiés. Instituto de Investigaciones Pesqueras, Barcelona, 1, 479-487.

Postel, L., 1987. Einfluß des Nouakchott-Cañons (Mauretanien) auf ozeanologische Feldverteilungen im März 1984. 6. Zooplanktonbiomasse. - Beitr. Meeresk. 57, 85-94.

Postel, L., 1990. The mesozooplankton response to coastal upwelling off West Africa with particular regard to biomass. - Meereswiss. Ber. 1, 1-127.

Reimer, L. W., 1977. Larval cestodes in plankton invertebrates of the Atlantic near the shore of North West Africa. - Parazitologija 11, 309-315.

Reimer, L. W., Hnatiuk, S. \& Rochner, J., 1975. Metacercarien in Planktontieren des mittleren Atlantik. - Wiss. Z. pädag. Hochsch. Güstrow (Math.-nat. Fak.) 2, 239-258.

Schemainda, R. \& Schulz, S., 1976. Investigations on space-temporal variations of oceanological fields and their effect on primary production in the upwelling region off Cap Blanc from 1971 to 1974. - Geod. geophys. Veröff. (Reihe 4) 18, 4-54.

Smed, J.,1982. The oceanographic data base for the CINECA region. - Rapp. P.-v. Réun. Cons. int. Explor. Mer 180, 11-28.

Speth, P., Detlefsen, H. \& Sierts, H. W., 1978. Meteorological influence on upwelling off Northwest Africa. - Dt. hydrogr. Z. 31, 95-104.

Sverdrup, H. U., Johnson, M. W. \& Fleming, R. H., 1942. The oceans, their physics, chemistry and general biology. Prentice Hall, Englewood Cliffs, $1087 \mathrm{pp}$.

Tomczak, M., 1973. An investigation into the occurence and development of cold water patches in the upwelling region off NW Africa, "Meteor". cruise No. 19. - "Meteor" Forsch.Ergebn. (Reihe A) $13,1-42$.

Tomczak, M. \& Hughes, P., 1980. Three-dimensional variability of water masses and currents in the Canary Current upwelling region. - Meteor-Forsch.Ergebn. (Reihe A) 21, 1-24.

Tomczak, M. \& Large, D. G. B., 1989. Optimum multiparameter analysis of mixing in the thermocline of Eastern Indian Ocean. - J. geophys. Res. (Reihe C) 94, 16141-16149.

Tranter, D. J. (Ed.), 1968. Monographs on oceanographic methodology 2: Zooplankton sampling. Unesco, Paris, $174 \mathrm{pp}$.

Weiß, R. \& Postel, L., 1991. Relationships between the mesozooplankton net growth and the Chub Mackerel stock off Northwest Africa. - C.M./ICES L:14.

Wolf, G. \& Kaiser, W., 1978. Über den Jahreszyklus der T-S-Eigenschaften quasipermanenter Wasserarten und Variationen produktionsbiologischer Parameter auf dem Schelf vor Cap Blanc. - Geod. geophys. Veröff. (Reihe 4) 24, 1-81.

Wranik, W. \& Arndt, E. A., 1978. Untersuchungen zur Systematik und Verbreitung der Thaliaceen vor Nordwestafrika. - Wiss. Z. Univ. Rostock (Math.-nat. R.) 27 (4), 381-388. 